\title{
DOROTHY CROSS JENSEN, 1906-1972
}

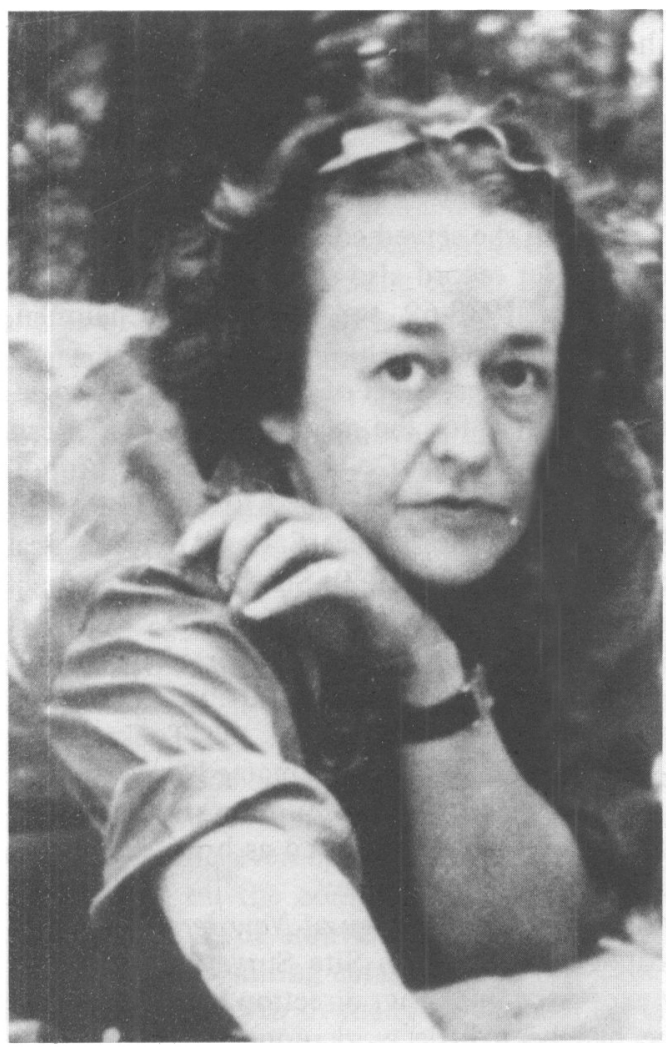

WHEN Dorothy Cross Jensen died of pneumonia in Trenton, New Jersey, on February 28, 1972, American archaeology lost one of its senior, thoroughly respected, hard-working, and totally committed professionals. She had led an active life in research and writing, and also in teaching. Although she pursued both concurrently, and although these 2 spheres overlapped to some extent, for the most part she kept them compartmentalized, and it is therefore necessary to treat them separately. Underlining this dichotomy is the fact that she signed her professional papers with her maiden name of Dorothy Cross, whereas at Hunter College she used her married name of Jensen.

She was born in Bala Cynwyd, grew up in the Philadelphia area and attended the University of Pennsylvania, where she took a B.S. in Education in 1928, and her doctorate in Oriental Studies and Anthropology in 1936. While a graduate student in 1931-32, she served as registrar for the excavations at Tell Billa and at Tepe Gawra, at that time under the directorship of the late Professor Ephraim A. Speiser. From 1930 to 1938 she held the posts of Assistant and Assistant Curator at the University of Pennsylvania Museum.

Despite the fact that most of her research life was devoted to the archaeology of New Jersey, 2 significant publications resulted from her early involvement with the Middle East. The first of these was her chapter, "The Pottery of Tepe Gawra," which dealt with the ceramics of the upper levels, I-VIII or, according to Speiser's formulation, from the Jemdet Nasr-Early Dynastic to the Hurrian Period. At a time when pottery received little attention in the Middle East, this chapter categorized various significant types descriptively, and was concerned with the internal developments at the site with regard to observable changes and developments from level to level in wares, shapes, and decoration. The only external comparisons were with the wares of Tell Billa, with which she was also familiar. It became something of a model from which many of the subsequent studies of Middle Eastern archaeological ceramics developed. (The pottery from earlier levels and from those subsequent excavations in which she did not take part was published by A.J. Tobler in 1950.)

Her dissertation, "Movable Property in the Nuzi Documents," presented in 1936, appeared under the same title in 1937 as a 65-page monograph of the American Oriental Society. This is a workmanlike organization of economic information scattered through the mostly private archives of a single site over a hundred-year span. Her analysis was restricted to material translated up to that time from the cuneiform, and consisted of family records, business transactions, court proceedings, and some miscellaneous tablets. Substantively she dealt with metrology, domestic animals, produce, metals, wool and clothing, implements, and some other objects, and examined them with regard to terminology and type of text, as well as their prices in terms of other 
commodities which were further summarized in a table of relative values. Although there have been virtually no additional studies of this nature, this work is considered a classic, utilized repeatedly by students in the field.

She was, of course, much more familiar to American archaeologists by virtue of her associations, excavations, and publications concerning New Jersey archaeology. Her initial exposure began in 1929 as an assistant at the New Jersey State Museum, and as a field supervisor there in 1931, but this was interrupted and overlapped by her employment at the University of Pennsylvania Museum from 1930-38, when she was primarily concerned with Middle Eastern archaeology.

In 1938, however, she simultaneously embarked upon her 2 careers of teaching at Hunter College and as Archaeologist at the New Jersey State Museum. She was a charter member of the Society for Pennsylvania Archaeology beginning in 1929, and an honorary member of the Archaeological Society of New Jersey from 1937, for which she served continuously as a member of its Executive Board and in 1966-68 as its Secretary. Her record also shows her as Recording Secretary for the Eastern States Archaeological Federation, 1938-69, and its Program Chairman, 1940-60. Affiliations with all of these organizations lasted until her death.

In addition, she served as Local and Program Chairman for Section $\mathrm{H}$ of the American Association for the Advancement of Science in 1945, Local Chairman for the meeting of the American Association of Physical Anthropologists in New York in 1952, and as Co-chairman for Anthropology, New York Academy of Sciences, for 3 yr in the 1950's. She is listed as Assistant Editor for the Archaeological Society of New Jersey from 1942, and for the Eastern States Archaeological Federation and for the New Jersey Academy of Science, both from 1960. She became a Council Member of this last in 1964.

Her major fieldwork in New Jersey began in 1936 when she became supervisor of the Indian Site Survey of New Jersey, a WPA project that lasted until 1942 and was allotted approximately a quarter of a million dollars. Most recently she was officially supervisor of the Tocks Island Reservoir Area excavations for the National Park Service, 1959-67, and remained a consultant thereafter. Throughout this period, as a member of the New Jersey State Museum staff, she took charge of numerous small and salvage excavations, most of which appeared as brief descriptive notes in the various Newsletters of the Archaeological Society of New Jersey.

Her 2 major publications in this field are her 2 volumes of Archaeology of New Jersey. Volume 1 (1941) consists of brief descriptions of sites located by the Indian Site Survey and detailed accounts of 39 sites in various parts of New Jersey excavated under her direction between March, 1936 and June, 1940. Previous to that time there had been little work done, and this was a systematic approach to assembling adequate and reliable data in an effort to answer a series of questions that had arisen because of uneven exploration and lack of comparability. As a result of her excavations, it was possible to obtain a much clearer picture of the archaeological background of New Jersey, to establish that the so-called "argillite culture" was not a distinct entity, and to identify the prehistoric Indian cultures of the area as coastal Algonkin, or as a coastal aspect of the northeastern phase of the Woodland pattern. In general, she tied northern New Jersey to Bitchie's "late" focus, and southern New Jersey to his "early" focus. Most of New Jersey belonged in her Red Valley focus, which was "early."

The second volume, Archaeology of New Jersey, The Abbott Farm, appeared in 1956. This site had been famous since 1872 and had become highly controversial over more than half a century, with numerous investigators taking sides. Some of the argillite specimens bore a superficial resemblance to European Paleoliths, and some were found in outwash gravels. The debate was whether any material from this site could be properly assigned to the Paleolithic in the European sense.

Although V. J. Fewkes, Satterthwaite, and Cross had made a brief test in 1929, it was not until the beginning of the Indian Site Survey of New Jersey that Cross began her large scale excavations at Abbott Farm. This was the first site opened (April, 1936) and the last one closed (February, 1941). The site, a large aboriginal village which apparently shifted location through time, begins $3.2 \mathrm{~km}$ south of Trenton and stretches $5.6 \mathrm{~km}$ along the Delaware River Bluff.

Again extensive and careful excavation was followed by a workmanlike description and evaluation of the evidence. Although the "probable" span runs from the Paleo-Indian to the historic, 
the Paleo-Indian rests on only 4 fluted point fragments, for which there is no good stratigraphic evidence. She thought that Paleo-Indians probably traversed the area, but that true occupation of the site began about 3000 B.C. with the Archaic period. Most of the Archaic material, however, belongs to the later phases, which were fairly well represented. Following that, she was able to recognize Early, Middle, and Late Woodland complexes, and a post-A.D.1625 historic period. She closed her report with an attempted reconstruction of the way of life and culture history of the periods, based on the archaeological evidence.

A third publication, "New Jersey's Indians," New Jersey State Museum Report, No. 1, which appeared in 1965, is a 95 page outgrowth of her brief descriptive 8 page account, which first appeared in 1939 as Leaflet 7 of the Archaeological Society of New Jersey and was frequently reprinted and somewhat revised and expanded over the years. This represented in part the public educational aspect of her work at the Museum, and was not intended as a scientific contribution.

Dorothy Jensen's teaching career began at the summer school of Rutgers University, 1936-40, and as of 1938 her curriculum vitae lists her as an instructor at Hunter College as well. In 1947 she received an appointment as Assistant Professor. For the rest of her life she remained there, becoming a full Professor in 1962. From 1950 to 1957 she served the department as subchairman for anthropology, which at that time was still yoked with sociology. She proved to be an excellent administrator and organizer who concentrated on vital matters, could penetrate to the heart of a question, and who remained calm under pressure. She was on good terms with her associates.

Like most anthropologists who started teaching during this period, her training had been broad and, during a time of small budgets and small staffs faced with increasing enrollments, she taught a variety of courses, inaugurated new ones, and maintained a wide interest in various aspects of the field. She made effective use of unpublished ethnographic materials that she had gathered during her archaeological work in Iraq, and for some years she kept monkeys of one sort or another in her home for the sake of her informal professional interest in their behavior.

My own association with her began when our paths first crossed about 1930, when she was still a graduate student and well before she went to the Middle East. It resumed during my $14 \mathrm{yr}$ of teaching in the evening session at Hunter, 7 yr under her chairmanship, and during which we collaborated on the comparative exhibit, "New Jersey's Place in Culture History," assembled to celebrate the 25th anniversary of the Eastern States Archaeological Federation in the winter of 1956-57. The resulting catalogue was our joint work. The purpose of this particular exhibit was to illustrate the growth of many of the world's civilizations as seen through the time frame of New Jersey's prehistoric archaeological periods. Subsequently, in 1965, we both sat on the multi-college committee that eventually hammered out the Graduate Program in Anthropology of the fledgling City University of New York.

Although it has seemed necessary to separate her teaching career from that of her research and writing, and her association with Hunter College from that with the New Jersey State Museum at Trenton, her museum role also called for a great deal of effort in the way of public education by direct information and by the preparation of leaflets and exhibits, while conversely she did introduce some of her interested and more committed students to fieldwork, museum work, and the analysis of collections, largely those associated with her Trenton Museum operations.

Against today's pattern, some of her personal qualities may seem somewhat old fashioned, but they were definitely reassuring. She believed that to do one's job properly, honestly, and to the best of one's ability was to cover one's debt to society. She knew who she was, and she took a disinterested approach toward the matters in which she was involved.

Professionally she regarded her obligation as one of broadening the range of information and data and of organizing and interpreting within the limits of the data themselves. She had little patience with the formulation of hypotheses in advance of securing data, the selective approach of research to support preconceived ideas, or the stating of answers to questions before undertaking the research involved. She asked questions. She probably did not pursue her own interpretations far enough in terms of multiple possibilities, limiting herself to what seemed obvious or letting her organization of the material speak for itself. She was clearly an exponent of an inductive rather than a deductive approach, which, although in some ways limited, was definitely sound. Her contributions, therefore, are enduring but not flashy. 
There was a rock-ribbed integrity about her which she conveyed to her students. They recognized her basic compartmentalization of numerous professional commitments and respected it. She had little time for the usual run who took courses simply for credits, but for those who had a sincere interest in anthropology she was unobtrusively all kindness and helpfulness, constructive in her formal and informal counseling, and in her casual but pertinent comment and suggestion. Her concern seemed impersonal but, despite her own reserve, it manifested itself in detached observation-often made at the price of personal inconvenience-which her students and younger colleagues knew and appreciated. She not only had her own ideals of quality performance but, without verbalizing them or making them explicit, she communicated them, and the rising group of professionals and those with whom she worked were affected by her views and continue to carry them on.

She disliked pretentiousness but had a humorous tolerance of human weaknesses. One could disagree with her and fight bitterly with her but, so long as it was an honest disagreement, although she might be furious, she remained a fast friend.

Her home in Fallsington, Pennsylvania, was a third dimension in her life and served as a refuge from the demands of her dual career, a place where she could relax. It also became a center for numerous younger people of the area. Even before her husband's death in 1957, and still more so afterward, she welcomed there a colleague or student who needed sanctuary or a breathing spell of one sort or another.

Her last few years brought both bitter disappointment and frustration. At the Museum a change of direction shifted its emphasis away from the natural history and history of New Jersey to a concern with modern art, and she saw much that she had labored to construct over the years swept away and eliminated under the new policies. She was also dogged by ill health, the after effects of a mugging in Trenton, severe emphysema and low blood pressure. Although she had to reduce drastically the extent of her activities, she retained her basic commitments to the end. She had spoken occasionally of retirement, but her profession was her life and she died in harness as she would have wished.

Her fundamental influence reached far beyond the superficial limits of her identification with the prehistoric archaeology of New Jersey, a restricted field in which she was the dominant organizing force for over $30 \mathrm{yr}$. There was a quality of endurance and permanence about her and, even after an interlude of several years, one could pick up where one had left off, in mid-sentence and with no sense of interruption. It was simply good and heartwarming to know that she was still present and accounted for. Her former students, her colleagues, and her friends, many of whom fall into all 3 categories, are acutely aware of her absence.

\section{ROBERT W. EHRICH \\ Department of Anthropology Brooklyn College, CUNY}

Acknowledgments. I am deeply grateful to Francis P. Conant for his help and cooperation in the preparation of this obituary. I also wish to thank Ethel Boissevain, Margaret Caesar, Rena Gropper, Bonnie Gustav, Christopher Hamlin, Alice James, and Herbert C. Kraft for additional information, insights, and confirmatory judgments.

Selected Bibliography of Dorothy Cross Jensen*

1935

The pottery of Tepe Gawra. In Excavations at Tepe Gawra I, Levels I-VIII, by E. A. Speiser, pp. 38-61. American Schools of Oriental Research. University of Penn.sylvania Press.

1937

Movable property in the Nuzi documents. American Oriental Society Series 10.

*For a more complete bibliography, see the obituary by Francis P. Conant (American Anthropologist, forthcoming). 
1939

Indians of New Jersey. Archaeological Society of New Jersey, Leaflet 7.

1941

Archaeology of New Jersey. Vol 1. With chapters by Henry B. Kümmel, Horace G. Richards, and Nathaniel Knowles. Archaeological Society of New Jersey and the New Jersey State Museum, Trenton.

\section{6}

Archaeology of New Jersey. Vol 2. The Abbott Farm. Archaeological Society of New Jersey and The New Jersey State Museum, Trenton.

(with Robert W. Ehrich) New Jersey's place in culture history, 16,000 B.C.-A.D. 1625: a comparative exhibition. New Jersey State Museum, Trenton.

New Jersey's Indians. New Jersey State Museum, Trenton. 